\title{
Green Innovation, Managerial Concern and Firm Performance: An Empirical Study
}

\author{
Mingfeng Tang, ${ }^{1,2 *}$ Crace Walsh, ${ }^{3}$ Daniel Lerner, ${ }^{4,5}$ Markus A. Fitza ${ }^{6,7}$ and Qiaohua $\mathrm{Li}^{8}$ \\ ${ }^{1}$ Sino-French Innovation Research Center, Southwestern University of Finance and Economics, Chengdu, China \\ ${ }^{2}$ BETA, University of Strasbourg, Strasbourg, France \\ ${ }^{3}$ Whitaker Institute for Innovation and Societal Change, National University of Ireland Calway, Ireland \\ ${ }^{4}$ Deusto Business School, Universidad de Deusto, Bilbao, Spain \\ ${ }^{5}$ Universidad del Desarrollo, Chile \\ ${ }^{6}$ Frankfurt School of Finance and Management, Frankfurt am Main, Germany \\ ${ }^{7}$ University of Newcastle, Newcastle NSW, Australia \\ ${ }^{8}$ Northwest University for Nationalities, Lanzhou, China
}

\begin{abstract}
Extant literature, while often suggesting a positive link between green innovation and firm performance, is inconclusive. Moreover, the possibly moderating role of management has not been sufficiently considered. Using a unique dataset sampling 188 manufacturing firms in China, we examine how managerial concern (for green issues) moderates the relationship between green innovation and firm performance. We find that green process innovation and green product innovation both significantly (positively) predict firm performance, when not considering managerial concern for the environment. Once managerial concern is included, we observe that it compounds the positive effect of green process innovation on firm performance - but not product innovation, which no longer explains significant unique variance in firm performance. The findings hold various implications for future research and business policy. Copyright (c) 2017 John Wiley \& Sons, Ltd and ERP Environment
\end{abstract}

Received 25 December 2016; revised 24 June 2017; accepted 7 July 2017

Keywords: green production innovation; green process innovation; managerial concern; firm performance

Introduction

A

DOPTING GREEN PRACTICES IS AN IMPORTANT CONSIDERATION FOR TODAY'S FIRMS (SHU ET AL., 2016). RESOURCE LIMITATION, consumer preferences, societal pressures and regulatory policies are driving the need towards a more balanced approach to economic growth and environmental sustainability. China, in particular, home to I6 out of the world's top 20 most polluted cities (López et al., 2008; Dhakal, 2009), has seen many industries changing in order to adopt a 'green mindset' (Shu et al., 20I6). Interest in green innovation and related concepts (e.g. eco-innovation, sustainable innovation, and environmental innovation) has also grown within the management literature over the past two decades (Schiederig et al., 20II). Green innovation is comprised of product 
and process innovation. It captures improvements in product design and manufacturing processes that save energy, reduce pollution, minimize waste and decrease a firm's negative impact on the environment (Woo et al., 20I4; Chen et al., 2006; Chen, 2008; Dangelico and Pujari, 20I0; Chang, 20II). In recent decades the empirical discourse exploring the relationship between sustainable development and firm performance has grown (Hall and Wagner, 20I2); however, the results remain inconclusive (Trumpp and Guenther, 20I7; Lee and Min, 20I5; Lee et al., 20I6). The lack of an underpinning theoretical framework and difficulty accessing data are cited as barriers to further understanding the link between environmental issues and firm performance (Lee and Min, 20I5; Trumpp and Guenther, 20I7).

In addition to public and regulatory environmental policy, firms have myriad pressures to confront - from consumers and suppliers to developing new markets and competitive advantages to improving their corporate image (Weng et al., 20I5; Chen, 2008). Fundamentally, it remains unclear whether or when the pursuit of green innovation is likely to be profitable for a firm. Recent research highlights that the extent to which green innovation can be ultimately transformed into firm performance is likely shaped by management (see, e.g., Przychodzen et al., 2016). However, there remains ambiguity around the impact of green innovation on firm performance. Much of the extant research has either examined (solely) green product innovation (Driessen et al., 2013; Albino et al., 2009, 20I2) or green process innovation (Tseng et al., 2013) - or otherwise considers green innovation broadly without delineating product and process innovation (Lee and Min, 20I5; Aguilera-Caracuel and Ortiz-de-Mandojana, 20I3). The lack of any general consensus, let alone best practice, as it relates to the role of green innovation in firm performance indicates the need for future research. Based on the potential catalyzing role of management in green innovation (see, e.g., Przychodzen et al., 2016; Testa et al., 2016), we suggest and examine whether the level of managerial environmental concern affects the relationship between green innovation (both product and process) and firm performance.

This study advances the conversation with an evidence-based examination of the relationship between green product and process innovation, firm performance, and the potential moderating role of managerial environmental concern, using a unique dataset of I88 Chinese manufacturing firms. Following a brief overview of the contemporary literature, the paper discusses the relevant concepts and hypotheses. The study's method is then described, after which the results are presented. The latter part of the paper discusses the findings and their relevance to business strategy practitioners and future research avenues.

\section{Literature Review and Conceptual Development}

\section{Green Innovation and Firm Performance}

Green innovation is comprised of green product innovation and green process innovation. Green product innovation is the production of a new product or service that inflicts no negative impact on the environment or less than the current or competing product (see, e.g., Wong et al., 20I2). Green process innovation is the improvement of existing production processes and use of environmentally friendly technologies to produce goods and provide services that impose no or reduced negative impact on the environment (see, e.g., Wong et al., 20I2). Firm performance, unless otherwise specified, typically refers to a firm's financial and associated indicators - i.e. sales, ROI, market share, stock market performance and related intangibles.

Empirical research exploring the relationship between environmental performance and firm performance presents mixed findings (Lee and Min, 2015). A meta-analysis of 64 empirical studies published between I978 and 2008 showed that $55 \%$ of the studies found a positive, $15 \%$ a negative, and $30 \%$ a null effect of environmental performance on firm performance (Horváthová, 20I0). Studies that have focused specifically on green innovation (and related concepts, e.g. eco-innovation, sustainable innovation, environmental innovation) also remain inconclusive. Some empirical research and theoretical perspectives posit that green innovation has a negative effect on firm performance. Specifically, Driessen et al. (20I3) found that green product innovation is associated with low financial performance. Aguilera-Caracuel and Ortiz-de-Mandojana (2013) observe that green innovative firms do not experience increased financial performance compared with non-green innovative firms. Other research (e.g. Liu et al., 20II) found that green innovation led to an increase in costs. Recently, a review of 63 studies published between I991 and 20I3 concluded that 
green product innovation improves firm performance (Dangelico, 20I6); of these 63 studies only three even considered China - one of the fastest growing economies, with one of the largest environmental footprints.

Reflecting a more complex reality, a comprehensive study recently appearing in Business Strategy and the Environment examined a sample of 2I8I firms and nine types of green process innovation - finding that only two of nine positively impact firm performance (Doran and Ryan, 20I6). These findings are broadly in line with the traditional economics perspective that green innovation is costly, and as such it often has a negative or null impact on firm performance (Palmer et al., I995; Lee et al., 2016).

However, the aforementioned fails to explain the various studies finding a positive effect (see Lee and Min, 20I5). For example, investigating the Spanish FTSE4 Good IBEX index, Charlo et al. (2015) show that socially responsible firms obtain higher profits for the same level of risk. Similarly, Fujii et al. (2013) found a positive relationship between the reduction of $\mathrm{CO}_{2}$ emissions and financial performance amongst Japanese manufacturing firms. Callan and Thomas (2009) conducted an extensive study where a positive relationship emerged between corporate social performance and corporate financial performance. Dangelico and Pontrandolfo (20I5) examined product and process related environmental actions, ultimately finding a positive link between these actions and firm performance; however, they also cite the importance and relevance of management throughout. Focusing on green innovation, Chen et al. (2006) show that the performance of green product and process innovation is positively correlated to competitive advantage. The review of the literature by Dangelico and Pujari (2010) uncovered an array of benefits emerging from integration of environmental sustainability issues with product development and business operations, including 'increased efficiency in the use of resources, return on investment, increased sales, development of new markets, improved corporate image, product differentiation, and enhanced competitive advantage' (p. 480). The theoretical perspective that addresses this relationship is based on the Porter and van der Linde (I995) hypothesis. The Porter hypothesis relates the effects of environmental regulation on technological innovation and economic performance. It asserts that innovation offsets can occur, with technological change 'partially or more than fully offset[ing] the costs of complying with environmental regulation' (Porter and van der Linde, I995, p. 98). In essence: innovation offsets the costs of environmental initiatives due to the technological change it stimulates; this in turn has the potential to make firms more competitive (Thurow and Holt, I997). Furthermore, green product innovation leads to a more efficient use of raw materials, transforming waste into a useful resource and ultimately decreasing costs (Porter and van der Linde, I995).

\section{Managerial Environmental Concern}

It is clear that evidence exists to support both sides of the argument about the impact of green innovation on firm performance. Given the ambiguity, a firm's engagement (or lack thereof) in green innovation is more a matter of managerial concern and decision-making than a matter of best practice or specified business policy. Research by Hahn and colleagues (20I4) suggests that 'a cognitive framing perspective offers a better understanding of managerial decision making on sustainability issues' (p. 482). Cognitive frames act as information filters wherein managers imbue ambiguous cues with meaning - which in turn results in them selecting and supporting particular strategic responses (Porac and Thomas, 2002; Weick, I995). The role of management in the translation of green innovation into firm performance is not to be ignored (Przychodzen et al., 20I6). The salience of any particular management concern - versus other competing stimuli and objectives - is a driving force of managerial attention and resources (see, e.g., Ocasio, I997; Shepherd et al., 20I7; Cho and Hambrick, 2006). We thus examine the environmental concern of management, given management's likely role as a catalyst. In particular, managers more concerned about green issues are apt to devote greater time/attention/support to such - potentially strengthening the likelihood of green innovation positively impacting firm performance (Bansal and Roth, 2000; Papagiannakis and Lioukas, 20I2; Papagiannakis et al., 2014).

\section{Hypotheses}

Following established convention in testing conditional (moderated) effects, to test the potentially moderating role of managerial environmental concern on the relationship between green innovation and firm performance, it is necessary to first formally note the general relation (i.e. green innovation-firm performance). Yet, as previously 
discussed, the impact of green innovation on firm performance remains ambiguous - and our research question is not about definitively settling the mixed main-effect results of prior research. Thus to proceed, based on the body of research indicating a positive relationship between green innovation and firm performance (Pujari, 2006; Gluch et al., 2009; Chiou et al., 20II; Chen et al., 2006), as a necessary step building to our primary hypothesis (H2) we will formally posit a positive general main effect.

Furthermore, distinguishing between product and process innovation is prudent. For example, Hall and Wagner (20I2, p. I84) found 'that only being a process innovator tends to positively influence environmental performance, whereas being purely a product innovator does not'. Accordingly, we delineate green innovation into product and process innovation. Based on the body of extant research and meta-analysis findings (Lee and Min, 2015) as a starting point (to later test moderated effects), we formally delineate the following main effects.

Hга: Green product innovation has a positive effect on firm performance.

Hib: Green process innovation has a positive effect on firm performance.

With regards to managerial concern, concern for the environment has a positive impact on the adoption of environmental innovation strategies (Bansal, 2003; Eiadat et al., 2008; Qi et al., 20I0; Testa et al., 20I6), whereby it acts as a trigger for pursuit of green innovation. This in turn might enhance firm performance (Ar, 20I2). ${ }^{\mathrm{I}}$ Furthermore, Dangelico (2015) argues that considering environmental aspects from the beginning is a critical success factor for green product innovation development.

Thus it is reasoned not only that managerial environmental concern may be important in determining if a firm will pursue green innovation, but also that the degree of concern may shape (moderate) the coupling of green innovation and firm performance. Building on and going beyond prior research, which only considered product innovation (Ar, 20I2), we examine the potentially moderating role of managerial environmental concern in the second set of hypotheses.

H2a: Managerial environmental concern has a positive moderating effect on the relationship between green product innovation and firm performance.

H2b: Managerial environmental concern has a positive moderating effect on the relationship between green process innovation and firm performance.

The primary hypothesis $\left(\mathrm{H}_{2}\right)$ and the overall model to be tested are illustrated in Figure I.

\section{Method}

\section{Study Context}

This study focuses on the Chinese manufacturing industry. Approximately one-third of world energy consumption and world $\mathrm{CO}_{2}$ emissions are due to the manufacturing industry (International Energy Agency, 2007). China, in particular, is the world's largest $\mathrm{CO}_{2}$ emitter (Olivier et al., 2016), and home to $\mathrm{I} 6$ of the world's 20 most polluted cities (López et al., 2008; Dhakal, 2009). However in recent years a drive to adopt a 'green mindset' is emerging (Shu et al., 20I6). The current legal environment compounds the relevance of this inquiry. Most acutely, in September 2016, China signed the Paris Climate Agreement. As such, our inquiry offers a timely examination of the way in which managerial environmental concern influences the link between green product/process innovation and firm performance, in the number one manufacturing economy.

\footnotetext{
IAs such, and absent a theoretical basis for why a manager's concern/beliefs should directly impact firm performance, we do not hypothesize such an effect. Concurrently, following standard model comparison statistical analyses, the regression models include the possibility of a main effect between said variables.
} 


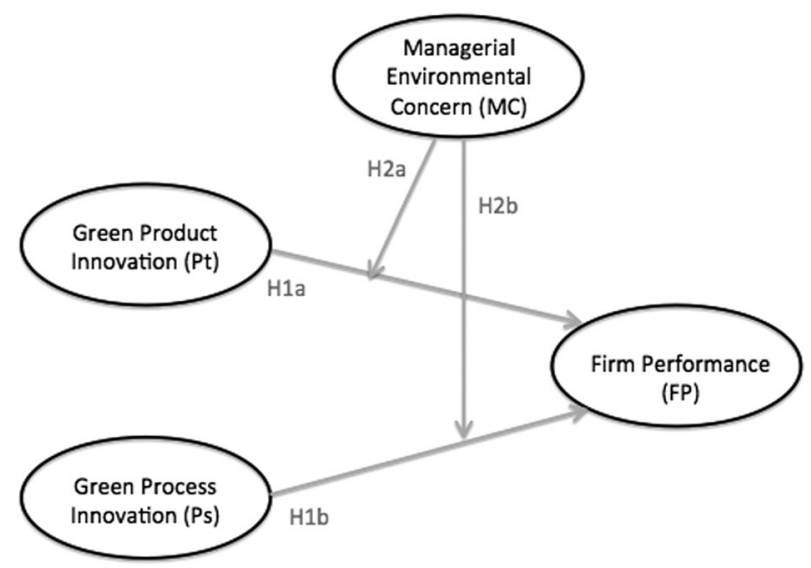

Figure 1. Conceptual research model

\section{Data Collection}

To test the hypotheses an original data collection was designed and conducted. After piloting the data-collection survey instrument, the finalized instrument was sent to organizations facilitating data collection: the EU Chamber of Commerce in China; the China Chamber of Commerce of Metals and Chemicals; the Jiangsu Yancheng Science and Technology Bureau; the Sichuan Hong County Reform and Development Bureau. Through these organizations the survey was distributed to managers of Chinese manufacturing firms, and completed by CEOs/general managers, production managers, R\&D managers or other TMT members. Of the 374 surveys distributed, I 88 valid responses were returned, representing a response rate of $50.3 \%$.

\section{Sample Characteristics}

Of the participating firms, $96.3 \%$ were SMEs and $93.6 \%$ were private firms. Sample characteristics are contained in Table I.

\section{Variable Measurement}

In this study the key variables are green product innovation, green process innovation, managerial environmental concern and firm performance. Multi-item scales operationalize each variable, based on existing literature as subsequently elaborated. In line with prior research, item responses were based on five-point Likert scales, scored from I (strongly disagree) to 5 (strongly agree).

Green Product Innovation (Pt)

Numerous existing studies have developed scales related to green product innovation (Wong et al., 20I2; Chen et al. 2006; Chen, 2008; Chiou et al., 20II). To develop valid measurements, the authors were guided by Chen et al.' $(2006,2008)$ definition of green innovation, which includes technology innovations linked to green product design, energy saving and pollution prevention. These studies informed the choice of items included in this research. In particular, respondents were asked about the materials, design, reusability/recyclability, packaging and labeling of new and existing products. Products using less energy, resources and materials in the development and design phase were seen as more favorable (Chen et al., 2006; Chen, 2008). The ease of recycling the product at the end of its life, the use of non-toxic materials (Chiou et al., 20II) and the use of environmentally friendly packaging (Wong et al., 2012) were other important considerations.

Green Process Innovation (Ps)

Operationalizing green process innovation required consideration of hazardous emissions, energy use and production operations during the manufacturing process (Wong et al., 2012; Chen et al., 2006; Chen, 2008; Chiou 


\begin{tabular}{|c|c|c|c|}
\hline \multirow[t]{4}{*}{ Respondent's managerial position } & CEO/general manager & 17 & 9.0 \\
\hline & R\&D manager & 24 & 12.8 \\
\hline & Production manager & 19 & 10.1 \\
\hline & Marketing manager & 56 & 29.8 \\
\hline \multirow[t]{5}{*}{ Ownership structure } & State owned or state holding company & 4 & 2.1 \\
\hline & Private company & 176 & 93.6 \\
\hline & Joint venture & 5 & 2.7 \\
\hline & Wholly foreign owned company & 2 & 1.1 \\
\hline & Other & 1 & 0.5 \\
\hline \multirow{2}{*}{ Firm age } & $15-20$ years & 11 & 5.9 \\
\hline & $\geq 20$ years & 21 & 11.2 \\
\hline \multirow[t]{3}{*}{ Firm size } & $\leq 100$ persons & 107 & 56.9 \\
\hline & 101-500 persons & 74 & 39.4 \\
\hline & $\geq 500$ persons & 7 & 3.7 \\
\hline
\end{tabular}

Table 1. Description of informants and firms

et al., 20II). Managers responded to questions about their respective firms' treatment of waste and emissions resulting from the production process (Chen et al., 2006; Chen, 2008). Energy consumption (Chiou et al., 20II), the use of cleaner technology, and clean transportation methods throughout production and dispatch (Wong et al., 2012) were also components of the green process innovation variable.

Managerial Environmental Concern (MC)

There is limited extant literature operationalizing managerial environmental concern. In an extensive literature review we only found three studies referencing it (Ar, 2012; Eiadat et al., 2008; Qi et al., 2010). After due consideration, this study adopted the four-item scale of Eiadat et al. (2008), also used by Ar (20I2). It reflects the relative salience of environmentally friendly innovation from a managerial perspective. In particular, it considers the centrality of environmental innovation to firm strategy - as well as the perceived effectiveness and importance of environmental innovation for achieving strategic goals.

Firm Performance (FP)

Based on prior research (namely Ar, 20I2; Hassan et al., 20I6; Chang and Fong, 20I0; Suki, 20I7), firm performance (FP) was operationalized based on five items covering sales volume $\left(\mathrm{FP}_{\mathrm{I}}\right)$, market share $\left(\mathrm{FP}_{2}\right)$, return on investment $\left(\mathrm{FP}_{3}\right)(\mathrm{Ar}, 20 \mathrm{I} 2)$, firm image $\left(\mathrm{FP}_{4}\right)$ (Hassan et al., 20I6) and customer satisfaction $\left(\mathrm{FP}_{5}\right)(\mathrm{Chang}$ and Fong, 20I0; Suki, 20I7). To allow and account for some of the items being more central to performance, a total variable score was derived with multivariate factor analysis of the five items; specifically, each item was weighted according to its multivariate factor loading.

Control Variables

In this study, the following control variables included: firm size, age and ownership structure. Firm size was operationalized based on number of employees (Marchi, 20I2; Walker and Wan, 20I2; Berrone et al., 2013; Huang and $\mathrm{Li}, 20 \mathrm{I5})$, condensed into three levels. Firm age was operationalized based on years since incorporation (Westman and Thorgren, 20I6; Huang and Boateng, 2013; Ke, 2008; Tian and Estrin, 2008; Hess et al., 2008), condensed into six levels. Ownership structure was categorical, with fixed effects as a control. 
The basis for including these controls was established on prior research and the following logic. Older and larger firms hold more experience and resources to potentially develop environmental innovations. Ownership structure was considered as current literature provides conflicting results as to its relevance to firm performance. Given that the study focuses on the Chinese manufacturing industry solely, a separate control for industry was not included.

\section{Data Analysis and Results}

\section{Common Method}

As firm managers completed the survey, the potential for common method bias was considered. In terms of procedural controls, respondents completed the survey anonymously, and the items within the survey were easy to understand. Furthermore, different variables measuring disparate items were separated clearly across the survey. In terms of quantitatively assessing whether common method might none the less still be present, a Harman single factor evaluated the potential existence of common method biases. The test resulted in a single-factor, chi square value of $843.897(\mathrm{df}=\mathrm{I52})$. Its degree of fit was substantially lower than that of the multi-factor measurement model $430.258(\mathrm{df}=\mathrm{I} 47)\left(\Delta \chi^{2}(\mathrm{df}=5)=4 \mathrm{I} 3.639, P<0.0 \mathrm{I}\right)$. Therefore, the effect of common method biases is deemed acceptable.

\section{Descriptive Analysis}

Table 2 provides descriptive statistics and variable intercorrelations.

\section{Reliability and Validity}

A series of tests was run to check the reliability and validity of the valid responses. The coefficient of Cronbach's alpha and corrected item-total correlation (CITC) analyze reliability, whilst KMO and Bartlett's ball test evaluate validity. The results supported the reliability and validity of the scales (see Tables 5 and 6 in the appendix for details).

\section{Collinearity Tests and Hypothesis Testing}

Before running hypothesis testing regressions, collinearity issues (Rong, 2005) and potential autocorrelation (Ma, 2002) were explored. When considering collinearity, it is necessary to conduct multicollinearity tests, essentially meaning that all control variables and independent variables are put into the model and the tolerance and variance inflation factor (VIF) of each variable is analyzed. The Durbin-Watson (DW) method is also adopted to test the sample data for residual independence. Analysis results (see Table 3) show that the tolerance of all variables is above

\begin{tabular}{|c|c|c|c|c|c|c|c|}
\hline 1. Firm age variable & 3.35 & 1.366 & & & & & \\
\hline 3. Managerial concern for env. & 4.41 & 0.640 & -0.012 & $0.150^{*}$ & & & \\
\hline 4. Green product innovation & 4.37 & 0.569 & 0.016 & $0.167^{*}$ & $0.710^{* * *}$ & & \\
\hline 5. Green process innovation & 4.27 & 0.577 & -0.031 & $0.166^{*}$ & $0.620^{* * *}$ & $0.705^{* * *}$ & \\
\hline
\end{tabular}

Table 2. Descriptive analysis

$* P<0.1$

** $P<0.05$,

** $P<0.01$. Ownership structure was categorical and is not shown here 


\begin{tabular}{|c|c|c|c|c|}
\hline \multirow[t]{2}{*}{ Variable } & \multicolumn{4}{|c|}{ Firm performance } \\
\hline & Model 1 & Model 2 & Model 3 & Model 4 \\
\hline Firm age var. & -0.118 & -0.081 & -0.075 & -0.093 \\
\hline Firm size var. & 0.105 & 0.002 & -0.013 & -0.008 \\
\hline Green product innovation $(\mathrm{Pt})$ & & $0.342^{* * * *}$ & 0.107 & 0.088 \\
\hline Managerial concern (MC) & & & $0.456 * * *$ & $0.517^{* * * *}$ \\
\hline$M C * P t$ & & & & -0.044 \\
\hline$M C *$ Ps & & & & $0.180^{* * *}$ \\
\hline$R^{2}$ & 0.02 & 0.31 & 0.41 & 0.43 \\
\hline Adjusted $R^{2}$ & 0.01 & 0.29 & 0.39 & 0.40 \\
\hline$F$ value & 1.30 & $16.45^{* * * *}$ & $20.95^{* * * *}$ & $16.82^{* * * *}$ \\
\hline
\end{tabular}

Table 3. Regression model analysis

All the regression coefficients were standardized;

$* P<0.1$,

$* * P<0.05$,

$*{ }^{*} * 0.01$. Fixed ownership structure effects were insignificant and are not shown here

O.I, and VIF is less than 4. These results suggest that a regression analysis is suitable. The DW value (I.9II) approaches 2, thus it does not influence the accuracy of the $t$-test and F-test results.

Based on the conceptual research model, hierarchical regression analysis was employed in four steps - i.e. in four models. Model I contains only the control variables. Model 2 adds the green product and process innovation variables; Model 3 adds managerial concern; Model 4 adds the interactions between managerial concern and green innovation.

In Model I, the control variables have no discernible effects on firm performance. Once green product innovation and green process innovation are added in Model 2, $R^{2}$ jumps to 0.3I. As the parameter estimates show, both green innovation variables have a significant positive effect on firm performance. Individually both green product and process innovation are significant predictors of firm performance $(\beta=0.342$ and 0.259 respectively, $P<0.0 \mathrm{I})$.

Model 3, as a precursor to the focal moderated model (Model 4), adds managerial concern for the environment. This serves as the baseline to allow subsequent observation of the unique variance incrementally explained by the interaction variables in Model 4. While not hypothesized and a little beyond our immediate focus, the loss of predictive significance of product innovation in Model 3 is discussed at the end of this section.

Finally, Model 4 is the full model including two interactions: the $M C$-by-process and the $M C$-by-product interactions. In this model green process innovation has a significant positive impact on firm performance $(\beta=$ o.I47, $P<$ O.I) and the interaction between green process innovation and managerial concern is also significant $(\beta=0.180, P<0.05)$. Green product innovation, while still showing a positive coefficient, does not appear to significantly impact firm performance $(\beta=0.088, P>0 . \mathrm{I})$; similarly, the interaction between green product innovation and managerial concern is not significant. This provides support for Hypothesis $2 \mathrm{~b}$, but not for Hypothesis 2a. It indicates that managerial concern plays a moderating role in relation to process innovation - in particular, compounding the positive relationship between green process innovation and firm performance.

This suggests an interesting, complex relation between innovation, managerial concern and firm performance. To analyze this further we divide our sample of firms into two groups based on a mean split: those that are high (above average) in green product innovation and those that are low (below average). The supplemental analysis results (Table 4) indicate that, within firms above the average in product innovation, increased green product innovation does not significantly influence firm performance. This may be due to high levels of product innovation increasing production costs, which offset revenue and related benefits. 


\begin{tabular}{lll}
\hline $\mathrm{DV}=$ firm performance & Model 5 (bottom-half Pt firms) & Model 6 (top-half Pt firms) \\
\hline Process innovation & 0.132 & $0.269^{* * *}$ \\
$\quad$ Product innovation & $0.240^{*}$ & 0.074 \\
$R^{2}$ & 0.10 & 0.10 \\
Adjusted $R^{2}$ & 0.07 & 0.08 \\
$F$ value & $3.85^{* *}$ & $6.14^{* * * *}$
\end{tabular}

Table 4. Supplemental mean-split regression analysis: the effect of green product innovation on firm performance (within below versus above average product innovation firms)

All regression coefficients standardized;

* $P<0.1$

$* * P<0.05$

*** $P<0.01$

Given insignificance of controls, for simplicity simple results shown here.

\section{Implications and Conclusion}

This paper examines green innovation, managerial concern and firm performance. Specifically, four hypotheses are tested. The simplest results find that both green product and green process innovation have a positive main effect on firm performance (Нıа, Hib; Model 2). Furthermore, in line with our central research questions and thesis, managerial concern has a positive moderating effect on the relationship between green process innovation and firm performance ( $\mathrm{H} 2 \mathrm{~b})$.

There are numerous contributions arising from this empirical study. The Chinese data provides a unique, yet timely, context for research of this nature. Furthermore, the study supports, extends and clarifies existing research on the relationship between green innovation and firm performance. One of the ways this research differs from prior studies is by not just looking across firms overall, but also parsing firms according to green product innovation into two groups (high versus low) and testing whether, within the different groups, green product innovation has similar effects on firm performance. The research findings show that green product innovation has a significant positive influence on firm performance within the subsample of firms below the mean in it (but not those above it). This may be due to diminishing returns at the high end; in essence, it is easier and less expensive to increase relatively low-level green product innovation.

As a result of features of the external environment (e.g. government environmental protection laws and regulations), firms may be forced to conduct green product innovation. To achieve short-term performance results, some firms may conduct low-level green product innovation. The overall, more stable positive relationship between green process innovation and firm performance (Models 2,3 and 4) may be due to the possibility that in the long term green process innovation is more conducive for sustainable development within a firm than green product innovation (Xie et al., 2015). Its benefits also appear to be more readily harnessed when managers perceive the managerial/strategic relevance of green. Considering the greater control management has over its production processes (than end-products subject to more uncertain or more unstable consumer preferences/market acceptance), the finding makes sense - and is in line with the presented logic of managerial concern. It may be somewhat more challenging for a firm to alter and improve its production (i.e. manufacturing) processes - requiring greater managerial concern - but doing so may bear more stable fruit.

\section{Implications for Strategy}

The results suggest important implications for business strategy. Business managers should recognize that neither green product innovation nor green process innovation appears to undermine firm performance. On the contrary, both appear to have a positive simple main effect on firm performance. However, engaging in innovation of any type carries an element of risk - with product innovation it is necessary to consider both the cost of inputs and the costs of conversion and consumer acceptance risks. Increasing low-level green product innovation appears to positively impact firm performance - yet positive returns to increased product innovation are not observed within the upper 
half of green product innovators. Thus, especially for firms facing potential cannibalization of existing product lines - or increasing costs to further green product development - managers would be wise to look at process innovation opportunities. Furthermore, product innovation requires inputs from the environment and as such the firm's ability to convert product innovation into firm performance is dependent on its access to resources.

Green process innovation appears to have a positive effect on firm performance at low, moderate and high levels. It leads to an increase in the efficient use of inputs and/or increased efficiency in the conversion process. In comparison with green product innovation, it is apt to be less dependent on factors outside of the firm and so the firm ultimately has more control over this innovation type. An important outcome, from a strategy perspective, is the influence of managerial environmental concern. Managerial concern has a positive compounding effect on green process innovation's relationship to firm performance.

Thus, managers need to be aware of the importance of green innovation and open to engaging in green innovation practices. Corporate commitment to environmental issues centralizes this cause and in turn increases managerial environmental concern, which ultimately has a positive effect on firm performance (Pipatprapa et al., 20I7). Our findings suggest that the environment should not be a decoupled afterthought or have negligible strategic significance. The relevance of managerial environmental concern increases the positive effect of innovation on performance. Thus, by making the environment a managerially relevant, salient concern, firms can promote green innovation as a means of achieving improved performance.

\section{Implications for Policy}

Green innovation practices are advantageous for both firms and the wider society. These practices ought to be encouraged by government bodies and policy makers. While green process innovation at all levels showed a positive effect on firm performance, this was not ubiquitously the case with green product innovation. Government policy may encourage green innovation through either progressive measures such as grants and rebates or punitive measures such as tariffs and quotas. Such actions increase the salience of green innovation in the minds of managers, thereby promoting managerial environmental concern. As previously mentioned, China recently signed the Paris Climate Agreement; this signals a commitment by the Chinese government to curb emissions and environmental pollution. Encouraging and supporting green innovation is an important part of reducing emissions; this research highlights that green product innovation may need more governmental support than green process innovation, as without greater external encouragement it may not be readily adopted by organizations given its negligible impact on firm performance above certain levels.

\section{Limitations and Future Research}

As with all studies, there are also some limitations indicating opportunities for future research. Due to the lack of panel data, we cannot directly speak to the dynamic process of green innovative practices within firms. Second, although the sample is compelling, like prior studies it is circumscribed to a particular national context - in this case, China. Furthermore, considering the sheer volume of manufacturing firms in China a sample of I88 is relatively minuscule. Future research involving other contexts or alternative data sources, or that tracks firms and their innovation activities over time, would be useful. While this study focused solely on manufacturing firms, future studies could continue to take an even more fine-grained look at specific industries and explore how green innovations' relevance can be shaped by specific industries. Finally, future research can further open the black box of how managerial environmental concern, and associated cognition and action, shape the coupling between green innovation, strategic behavior and strategic outcomes such as firm performance.

\section{Acknowledgments}

We would like to thank the National Nature Science Foundation, China and Sichuan Education Administration Office for funding this research project under Grants G0302/7I40322I, G02040I/7I402I44 and I7SAoI95. 


\section{References}

Aguilera-Caracuel J, Ortiz-de-Mandojana N. 20I3. Green innovation and financial performance: an institutional approach. Organization and Environment 26(4): 365-385.

Albino V, Balice A, Dangelico RM. 2009. Environmental strategies and green product development: an overview on sustainability-driven companies. Business Strategy and the Environment $18(2): 83-96$.

Albino V, Balice A, Dangelico RM,Iacobone FA. 20I2. The effect of the adoption of environmental strategies on green product development: a study of companies on world sustainability indices. International Journal of Management 29(2): 525-538.

Ar IM. 20I2. The impact of green product innovation on firm performance and competitive capability: the moderating role of managerial environmental concern. Procedia - Social and Behavioral Sciences 62: 854-864.

Bansal P. 2003. From issues to actions: the importance of individual concerns and organizational values in responding to natural environmental issues. Organization Science I4(5): 510-527.

Bansal P, Roth K. 2000. Why companies go green: a model of ecological responsiveness. Academy of Management Journal 43: 7I7-736.

Berrone P, Fosfuri A, Gelabert L, Gomez-Mejia LR. 20I3. Necessity as the mother of 'green' inventions: institutional pressures and environmental innovations. Strategic Management Journal 34: 89I-909.

Callan S, Thomas JM. 2009. Corporate financial performance and corporate social performance: an update and reinvestigation. Corporate Social Responsibility and Environmental Management $\mathbf{1 6}(2)$ : 6I-78.

Chang CH. 20II. The influence of corporate environmental ethics on competitive advantage, the mediation role of green innovation. Journal of Business Ethics I04(3): 36I-370.

Chang NJ, Fong CM. 20I0. Green product quality, green corporate image, green customer satisfaction, and green customer loyalty. African Journal of Business Management 4(13): 2836-2844.

Charlo MJ, Moya I, Muñoz AM. 20I5. Sustainable development and corporate financial performance: a study based on the FTSE4Good IBEX Index. Business Strategy and the Environment 24(4): 277-288.

Chen YS. 2008. The driver of green innovation and green image - green core competence. Journal of Business Ethics 8I: 53I-543.

Chen YS, Lai SB, Wen CT. 2006. The influence of green innovation performance on corporate advantage in Taiwan. Journal of Business Ethics 67(4): 33I-339.

Chiou TY, Chan HK, Lettice F, Chung SH. 20II. The influence of greening the suppliers and green innovation on environmental performance and competitive advantage in Taiwan. Transportation Research Part E 47(6): 822-836.

Cho TS, Hambrick DC. 2006. Attention as the mediator between top management team characteristics and strategic change: the case of airline deregulation. Organization Science I7(4): 453-469.

Dangelico RM. 2015. Improving firm environmental performance and reputation: the role of employee green teams. Business Strategy and the Environment 24(8): 735-749.

Dangelico RM. 20I6. Green product innovation: where we are and where we are going. Business Strategy and the Environment 25: 560-576.

Dangelico RM, Pontrandolfo P. 20I5. Being 'green and competitive': the impact of environmental actions and collaborations on firm performance. Business Strategy and the Environment 24(6): 413-430.

Dangelico RM, Pujari D. 20I0. Mainstreaming green product innovation: why and how companies integrate environmental sustainability. Journal of Business Ethics 95(3): 47I-486.

Dhakal S. 2009. Urban energy use and carbon emissions from cities in China and policy implications. Energy Policy 37(II): 4208-42I9.

Doran J, Ryan G. 20I6. The importance of the diverse drivers and types of environmental innovation for firm performance. Business Strategy and the Environment 25: IO2-II9.

Driessen PH, Hillebrand B, Kok RA, Verhallen TM. 20I3. Green new product development: the pivotal role of product greenness. IEEE Transactions on Engineering Management 6o(2): 315-326.

Eiadat Y, Kelly A, Roche F, Eyadat H. 2008. Green and competitive? An empirical test of the mediating role of environmental innovation strategy. Journal of World Business 43(2): I3I-I45.

Fujii H, Iwata K, Kaneko S, Managi S. 20I3. Corporate environmental and economic performance of Japanese manufacturing firms: empirical study for sustainable development. Business Strategy and the Environment 22(3): I87-20I.

Gluch P, Gustafsson M, Thuvander L. 2009. An absorptive capacity model for green innovation and performance in the construction industry. Construction Management and Economics 27(5): 45I-464.

Hahn T, Preuss L, Pinkse J, Figge F. 20I4. Cognitive frames in corporate sustainability: Managerial sensemaking with paradoxical and business case frames. Academy of Management Review 39(4): 463-487.

Hall J, Wagner M. 20I2. Integrating sustainability into firms' processes: performance effects and the moderating role of business models and innovation. Business Strategy and the Environment 21(3): 183-196.

Hassan Y, Balan S, Prakash V. 20I6. The impact of implementing green supply chain management practices on corporate performance. Competitiveness Review 26(3): 216-245.

Hess K, Gunasekarage A, Hovey M. 2008. State dominant and non-state dominant ownership concentration and firm performance: evidence from China. International Journal of Managerial Finance 6: 264-289.

Horváthová E. 20Io. Does environmental performance affect financial performance? A meta-analysis. Ecological Economics 70(I): 52-59.

Huang JW, Li YH. 20I5. Green innovation and performance: the view of organizational capability and social reciprocity. Journal of Business Ethics. https://doi.org/I0.I007/sI055I-0I5-2903-y

Huang W, Boateng A. 20I3. The role of the state, ownership structure, and the performance of real estate firms in China. Applied Financial Economics 23(10): 847-859. 
International Energy Agency (IEA). 2007. Tracking Industrial Energy Efficiency and $\mathrm{CO}_{2}$ Emissions. Retrieved from, https://www.iea.org/publications/freepublications/publication/tracking_emissions.pdf. [6 September 20I7].

Ke Q. 2008. Are state-owned companies underperforming? A case study of Chinese listed property companies. Journal of Real Estate Literature I6: I83-200.

Lee KH, Cin BC, Lee EY. 20I6. Environmental responsibility and firm performance: the application of an environmental, social and governance model. Business Strategy and the Environment 26(I): 40-53.

Lee KH, Min B. 20I5. Green R\&D for eco-innovation and its impact on carbon emissions and firm performance. Journal of Cleaner Production Io8: $534-542$.

Liu X, Dai H, Cheng P. 20II. Drivers of integrated environmental innovation and impact on company competitiveness: evidence from I8 Chinese firms. International Journal of Technology and Globalisation 5: 255-280.

López RE, Thomas V, Wang Y. 2008. The quality of growth: fiscal policies for better results. IEG World Bank Working Paper $2008 / 6$.

Ma QG. 2002. Management Statistics - Data Acquisition, Statistical Theory, SPSS Tools and Application Research. Science: Beijing.

Marchi VD. 20I2. Environmental innovation and R\&D cooperation: empirical evidence from Spanish manufacturing firms. Research Policy 4I: 6I4-623.

Ocasio W. I997. Towards an attention-based view of the firm. Strategic Management Journal 18: I87-206.

Olivier J, Janssens-Maenhout G, Muntean M, Peters J. 20I6. “Trends in global CO2 emissions: 2016 Report” PBL Netherlands Environmental Assessment Agency and European Commission Joint Research Centre - Report: 2315. Retrieved from, http://www.pbl.nl/en/publications/trends-in-global-co2-emissions-2016-report. [6 September 20I7].

Palmer K, Oates W, Portney P. I995. Tightening environmental standards: the benefit-cost or the no-cost paradigm? Journal of Economic Perspectives 9(4): II9-I32.

Papagiannakis G, Lioukas S. 20I2. Values, attitudes and perception of managers as predictors of corporate environmental responsiveness. Journal of Environmental Management Ioo: 4I-5I.

Papagiannakis G, Voudouris I, Lioukas S. 20I4. The road to sustainability: exploring the process of corporate environmental strategy over time. Business Strategy and the Environment 23: 254-27I.

Pipatprapa A, Huang HH, Huang CH. 20I7. The role of quality management \& innovativeness on green performance. Corporate Social Responsibility and Environmental Management 24(3): 249-260.

Porac JF, Thomas H. 2002. Managing cognition and strategy: issues, trends and future directions. In Handbook of Strategy and Management, Pettigrew AM, Thomas H, Whittington R (eds). Sage: Beverly Hills, CA; I65-I8I.

Porter ME, van der Linde C. I995. Toward a new conception of the environment-competitiveness relationship. Journal of Economic Perspectives 9(4): 97-II8.

Przychodzen W, Przychodzen J, Lerner D. 20I6. Critical factors for transforming creativity into sustainability. Journal of Cleaner Production I35: I5I4-I523.

Pujari D. 2006. Eco-innovation and new product development: understanding the influences on market performance. Technovation 26(I): $76-85$.

Qi GY, Shen LY, Zeng SX, Jorge OJ. 20I0. The drivers for contractors' green innovation: an industry perspective. Journal of Cleaner Production I8: I358-I365.

Rong TS. 2005. Business Research Methods. China Taxation Press: Beijing.

Schiederig T, Tietze F, Herstatt C. 20II. What is Green Innovation? A quantitative literature review. http://papers.ssrn.com/sol3/papers.cfm?abstract_id=I846882 [6 September 20I7].

Shepherd DA, McMullen JS, Ocasio W. 20I7. Is that an opportunity? An attention model of top managers' opportunity beliefs for strategic action. Strategic Management Journal 38(3): 626-644.

Shu C, Zhou KZ, Xiao Y, Gao S. 20I6. How green management influences product innovation in China: the role of institutional benefits. Journal of Business Ethics 133(3): 47I-485.

Suki NM. 20I7. Green products usage: structural relationships on customer satisfaction and loyalty. International Journal of Sustainable Development and World Ecology 24(I): 88-95.

Testa F, Gusmerottia NM, Corsini F, Passetti E, Iraldo F. 20I6. Factors affecting environmental management by small and micro firms: the importance of entrepreneurs' attitudes and environmental investment. Corporate Social Responsibility and Environmental Management 23(6): $373-385$.

Thurow AP, Holt J. I997. Induced policy innovation: environmental compliance requirements for dairies in Texas and Florida. Journal of Agricultural and Applied Economics 29(OI): I7-36.

Tian L, Estrin S. 2008. Retained state shareholding in Chinese PLCs: does government ownership reduce corporate value? Journal of Comparative Economics 36: 74-89.

Trumpp C, Guenther T. 20I7. Too little or too much? Exploring U-shaped relationships between corporate environmental performance and corporate financial performance. Business Strategy and the Environment 26: 49-68.

Tseng ML, Tan RR, Siriban-Manalang AB. 20I3. Sustainable consumption and production for Asia: sustainability through green design and practice. Journal of Cleaner Production 40: I-5.

Walker K, Wan F. 20I2. The harm of symbolic actions and green-washing: corporate actions and communications on environmental performance and their financial implications. Journal of Business Ethics I09: 227-242.

Weick KE. I995. Sensemaking in Organizations (Vol. 3). Sage: Thousand Oaks, CA.

Weng HHR, Chen JS, Chen PC. 20I5. Effects of green innovation on environmental and corporate performance: a stakeholder perspective. Sustainability 7(5): 4997-5026. 
Westman C, Thorgren S. 20I6. Partner conflicts in international joint ventures: a minority owner perspective. Journal of International Management 22(2): I68-I85.

Wong CWY, Lai K, Shang KC, Lu CS, Leung TKP. 20I2. Green operations and the moderating role of environmental management capability of suppliers on manufacturing firm performance. International Journal of Production Economics I4O(I): $283-294$.

Woo C, Chung Y, Chun D, Han S, Lee D. 20I4. Impact of green innovation on labor productivity and its determinants: an analysis of the Korean manufacturing industry. Business Strategy and the Environment 23(8): 567-576.

Xie X, Huo J, Qi G, Zhu KX. 20I5. Green process innovation and financial performance in emerging economies: moderating effects of absorptive capacity and green subsidies. IEEE Transactions on Engineering Management 63(I): I-I2.

\section{Appendix A. Reliability and Validity Analysis Details}

The tables here provide the results of tests run to test the reliability and validity of the valid responses. The results supported the reliability and validity of the scales. The coefficient of Cronbach's alpha of every measurement item excluding itself and every variable overall is greater than 0.7; the CITC of each measurement item is above 0.5 , supporting scale reliability. The KMO values of all variables are greater than 0.7 , and Bartlett's ball test is significant, supporting scale validity.

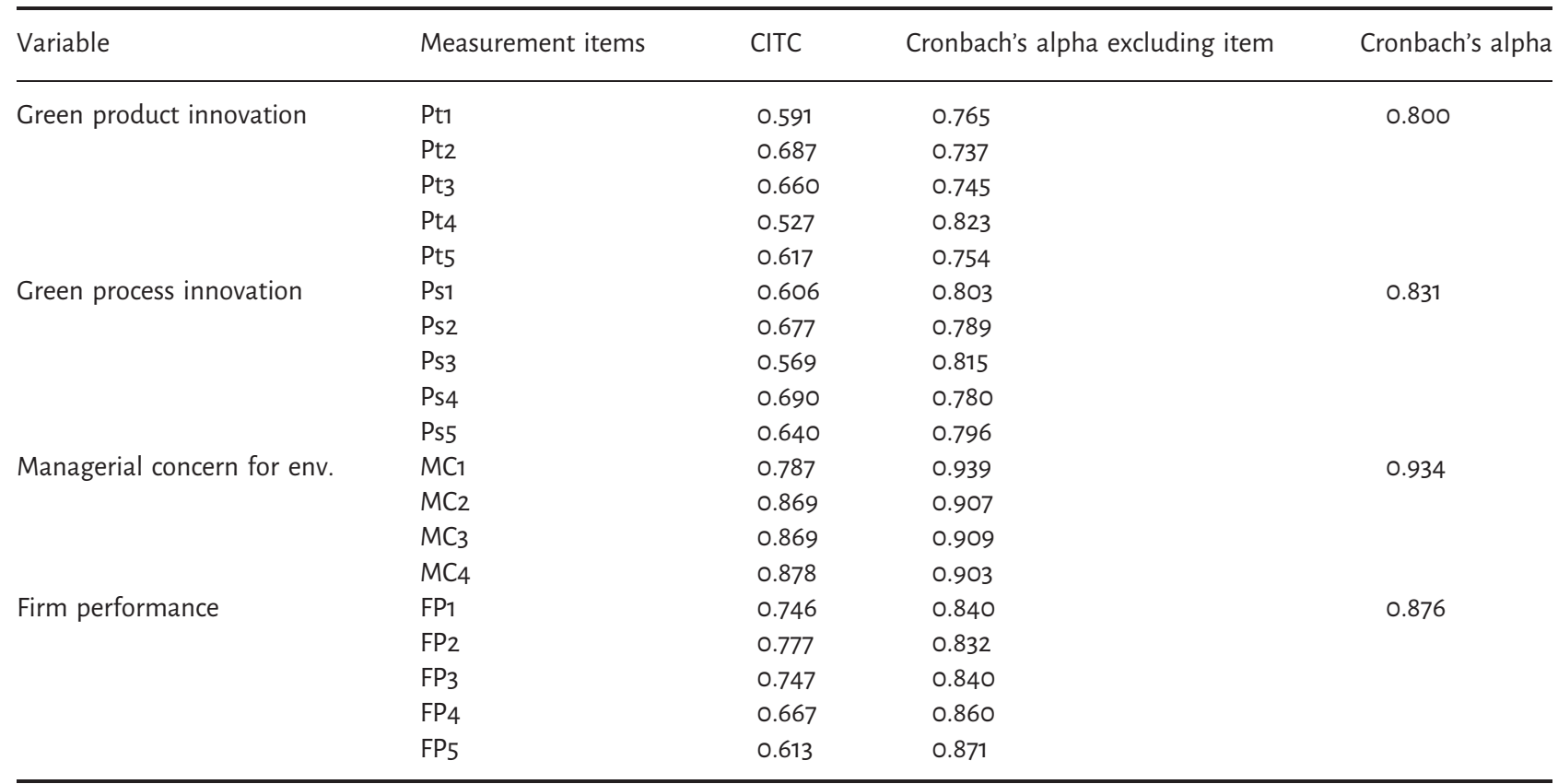

Table A1. Reliability analysis

\begin{tabular}{|c|c|c|c|c|c|}
\hline $\mathrm{KMO}$ value & & 0.826 & 0.825 & 0.863 & 0.796 \\
\hline Bartlett's ball test & Approx. chi square & 338.074 & 341.970 & 672.071 & 540.526 \\
\hline Degrees of freedom & 10 & 10 & 6 & 10 & \\
\hline Significance & 0.000 & 0.000 & 0.000 & 0.000 & \\
\hline
\end{tabular}

Table A2. Validity analysis 